\title{
KORELASI ANTARA TINGKAT PENDIDIKAN DAN HARAPAN SERTA PERSEPSI PASIEN DALAM PELAYANAN KEFARMASIAN DI APOTEK "X" DI DAERAH SEMINYAK
}

\section{(CORELATION OF EDUCATION DEGREE AND PATIENT EXPECTATION-AND-PATIENT PERCEPTION OF PHARMACEUTICAL CARE IN PHARMACY “X” IN SEMINYAK)}

\author{
NI PUTU UDAYANA ANTARI ${ }^{1}$, FITRIA MEGAWATI $^{1}$, I PUTU TANGKAS SUWANTARA $^{1}$ \\ ${ }^{1}$ Akademi Farmasi Saraswati Denpasar, Jalan Kamboja No.11A, Denpasar, Bali
}

\begin{abstract}
Abstrak: Apotek selaku penyedia jasa dituntut untuk dapat memberikan pelayanan kefarmasian yang terbaik. Apotek dituntut untuk dapat memenuhi harapan pasien sehingga pasien puas terhadap pelayanan yang diberikan. Tingkat pendidikan seseorang mempengaruhi tingkat pengetahuan pasien, Pengetahuan seseorang mempengaruhi sudut pandangnya dalam menilai suatu pelayanan kefarmasian yang diperoleh. Dengan demikian penelitian ini bertujuan untuk mengetahui hubungan antara tingkat pendidikan pasien dan harapan serta persepsi antara pasien terhadap pelayanan kefarmasian yang dilakukan oleh Apotek " $\mathrm{X}$ " di daerah Seminyak. Penelitian ini menggunakan rancangan cross sectional yang dilaksanakan melalui penyebaran kuesioner yang memuat harapan dan persepsi kepada pasien yang berkunjung ke Apotek " $X$ " di daerah Seminyak. Kuesioner memuat pernyataan yang terbagi dalam 5 dimensi yaitu: reliability, responsiveness, assurance, tangibles, dan empathy. Kuesioner yang diisi responden diberi skor menggunakan skala Likert. Hasil penelitian menunjukkan bahwa ada korelasi signifikan antara tingkat pendidikan dan harapan terhadap pelayanan kefarmasian dengan arah korelasi positif dan tingkat korelasi lemah. Korelasi antara tingkat pendidikan terhadap pelayanan kefarmasian dan persepsi menunjukkan hasil yang signifikan dengan arah korelasi positif dan tingkat korelasi lemah.
\end{abstract}

Kata kunci : harapan, kualitas pelayanan kefarmasian, persepsi, tingkat pendidikan.

Abstract: Pharmacy as service providers are required to provide the best pharmacy service. Pharmacy required to meet the expectations of patients so that the patients are satisfied with the services provided. A person's education level affects the patient's level of knowledge, knowledge of a person influences his perspective in assessing pharmaceutical services obtained. Thus, this study aims to determine the relationship between education levels and expectations of patients and the perception among patients to pharmacy services conducted by the Pharmacy "X " in the Seminyak area. This study used cross sectional design conducted through questionnaires containing expectations and perceptions of patients who visit pharmacies " $\mathrm{X}$ " in the Seminyak area. The questionnaire contains statements that are divided into five dimensions: reliability, responsiveness, assurance, tangibles and empathy. Questionnaires filled respondents were scored using a Likert scale. The results showed that there was a significant correlation between level of education and the expectations of pharmacy services with a positive correlation direction and degree of correlation is weak. The correlation between level of education to pharmacy services and the perception of a significant result with a positive correlation direction and degree of correlation is weak.

Keywords: expectations, perceptions, level of education, the quality of pharmaceutical services.

\section{PENDAHULUAN}

Harapan pelanggan adalah keyakinan tentang pemberian pelayanan yang berfungsi sebagai standar dalam menilai kinerja. Karena pelanggan membandingkannya dengan persepsi pada saat menilai kualitas pelayanan, mengetahui harapan konsumen menjadi sangat penting bagi pemasar. Kesalahan dalam menilai keinginan pelanggan dapat mengakibatkan kehilangan pelanggan. Pelanggan biasanya mempersepsikan pelayanan berdasarkan kualitas pelayanan dan seberapa besar produk tersebut memuaskan keinginannya dibandingkan dengan pengalamannya secara keseluruhan (Zeithaml dan Bitner, 1996).

Menurut Robbins (2003) dideskripsikan bahwa persepsi merupakan kesan yang diperoleh oleh individu melalui panca indera kemudian dianalisa (diorganisir), diintepretasi dan kemudian

• email korespondensi: putuudayana87@gmail.com 
dievaluasi, sehingga individu tersebut memperoleh makna.

Berdasarkan Keputusan Menteri Kesehataan No. 35 Tahun 2014, apotek adalah sarana pelayanan kefarmasian tempat dilakukan praktik kefarmasian oleh Apoteker dimana standar pelayanan kefarmasian adalah tolak ukur yang dipergunakan sebagai pedoman bagi tenaga kefarmasian dalam menyelenggarakan pelayanan kefarmasian. Pelayanan Kefarmasian adalah suatu pelayanan langsung dan bertanggung jawab kepada pasien yang berkaitan dengan sediaan farmasi dengan maksud mencapai hasil yang pasti untuk meningkatkan mutu kehidupan pasien.

Persepsi konsumen terhadap pelayanan apotek yang buruk akan merugikan apotek dari aspek bisnis karena konsumen akan beralih ke apotek lain. Dampak yang timbul tidak saja kepada konsumen yang bersangkutan tetapi kesan buruk ini akan diceritakan kepada orang lain sehingga citra apotek, terutama para petugasnya, termasuk apoteker, akan negatif atau buruk. Oleh karena itu, persepsi konsumen yang baik terhadap layanan kefarmasian di apotek harus ditumbuhkan terus menerus dan berkesinambungan dengan orientasi kepada pelanggan itu sendiri.

Menurut Parasuraman et al., (1991), ada lima dimensi pokok kualitas pelayanan jasa yang dapat digunakan untuk mengukur tingkat kepuasan pelanggan yaitu responsiveness (ketanggapan), reliability (kehandalan), assurance (jaminan), emphaty (empati), tangibles (bukti langsung).

Menurut Tjiptono (2008) Banyak faktor yang mempengaruhi persepsi kepuasan terhadap suatu prodak atau jasa, diantaranya faktor pendapatan, faktor budaya, faktor status sosial, faktor tingkat pendidikan, faktor tingkat usia, faktor demografis dan masih banyak faktor yang lain.

Menurut Undang-Undang No. 20 Tahun 2003, indikator tingkat pendidikan terdiri dari jenjang pendidikan dan kesesuaian jurusan. Jenjang pendidikan adalah tahapan pendidikan yang ditetapkan berdasarkan tingkat perkembangan peserta didik, tujuan yang akan dicapai, dan kemampuan yang dikembangkan, terdiri dari Pendidikan dasar, pendidikan menengah, dan pendidikan tinggi.

Penelitian ini bertujuan untuk mengetahui hubungan antara tingkat pendidikan dengan harapan dan persepsi pasien. rumusan masalah dalam penelitian ini adalah : Apakah tingkat pendidikan berhubungan signifikan dengan harapan dan persepsi pasien di apotek " $X$ " di daerah seminyak?

\section{METODE PENELITIAN}

Rancangan Penelitian. Jenis penelitian yang dilakukan adalah penelitian cross sectional.

Populasi dan Sampel. Populasi adalah seluruh pasien di apotek "X" di Seminyak. Jumlah sampel penelitian diperoleh melalui perhitungan rumus menurut Lemeshow dkk. (1997) sebagai berikut:

$$
n=\frac{\mathrm{Z}_{1}{ }^{2}-\frac{\alpha}{2} \cdot \mathrm{p}(1-\mathrm{p})}{d^{2}}
$$

Keterangan:

$\mathrm{n} \quad$ : jumlah sampel minimal

$$
\begin{aligned}
& \mathrm{Z}_{1}{ }^{2}-\frac{\alpha}{2}: \text { derajad kepercayaan } 95 \%(1,96) \\
& \mathrm{p} \\
& \mathrm{d}
\end{aligned}
$$

Menurut rumus di atas, sampel penelitian minimal berjumlah 49 orang sehingga dalam penelitian ini diambil masing-masing 50 orang untuk responden yang berpendidikan terakhir pendidikan dasar, 50 orang responden yang berpendidikan terakhir pendidikan menengah dan 50 orang responden yang berpendidikan tinggi.

Pengambilan sampel dilakukan dengan sistem purposive sampling dengan kriteria inklusi dan eksklusi sebagai berikut :

Kriteria Inklusi :

1. Pasien yang membeli obat ke apotek dengan biaya sendiri.

2. Pasien dengan umur minimal 17 tahun.

3. Pasien bisa berkomunikasi, membaca, dan menulis dengan baik.

4. Pasien yang bersedia mengisi kuesioner.

Kriteria Eksklusi :

1. Pasien atau keluarga yang berasal dari pegawai apotek tersebut.

2. Pasien Jamkesmas, askes, dan asuransi swasta lainnya.

Instrumen Penelitian. Penelitian dilakukan dengan menyebarkan kuesioner yang dirancang dalam bentuk pernyataaan dengan jawaban tertutup. Pernyataan dibuat sesuai pengukuran kualitas pelayanan menurut Dari setiap pernyataan tersebut dirancang pernyataan dengan jawaban mendukung (favourable) dan untuk jawaban yang 
tidak mendukung (unfavorable). Skoring dilakukan menggunakan skala Likert. Kuesioner yang digunakan telah teruji validitas dan reliabilitasnya. Uji validitas dan reliabilitas dilakukan dengan menyebarkan kuesioner kepada 30 orang responden menggunakan metode one shot (sekali ukur).Uji validitas yang digunakan adalah tekhnik korelasi Product Moment Pearson. Kriteria pengujian adalah nilai " $r$ " hitung melebihi nilai " $r$ " tabel yaitu $>0,361$. Jika nilai " $r$ ' hitung telah melebihi 0,361 maka kuesioner tersebut dinyatakan telah valid. Kriteria pengujian reliabilitas adalah jika nilai Cronbach Alpha hitung $>60$, maka instrumen yang diuji tersebut dapat dinyatakan telah reliabel.

Pengolahan dan Analisis data. Pengambilan data dilakukan dengan menyebarkan kuesioner pada total 150 responden yang telah memenuhi kriteria inklusi dan eksklusi. Data yang telah diperoleh dilakukan proses "Coding" yang selanjutnya dilakukan analisis data dengan mencari total skor dari nilai yang telah diperoleh di setiap kuesioner. Untuk mencari hubungan antara tingkat pendidikan dengan harapan dan persepsi pasien, digunakan uji Spearman.

\section{HASIL DAN PEMBAHASAN}

Dalam pola interaksi sosial, persepsi pasien sangat berperan dalam menggambarkan tingkat kepuasan pasien terhadap pelayanan kefarmasian di apotek. Berdasarkan persepsi ini akan timbul kesan pasien terhadap apotek, yang selanjutnya dapat disebut sebagai kualitas pelayanan apotek. Kesan yang didapat dibangun atas persepsi masing-masing individu yang berelasi.Persepsi seseorang dapat berbeda satu sama lainnya, meskipun dihadapkan pada suatu situasi dan kondisi yang sama. Hal ini dipandang dari suatu gagasan bahwa semua menerima suatu objek rangsangan melalui penginderan, penglihatan, pendengaran, pembauan dan perasaan. Persepsi dan harapan pasien berkaitan dengan kepuasan terhadap mutu pelayanan kesehatan.

Berdasarkan teori bahwa makin tinggi tingkat pendidikan seseorang makin mudah menerima informasi sehingga makin banyak pula pengetahuan yang dimiliki. Sebaliknya pendidikan yang kurang akan menghambat perkembangan sikap seseorang terhadap nilai-nilai yang baru diperkenalkan (Nursalam, 2001).
Tabel 1. Hasil Uji Spearman Terhadap Korelasi Antara Tingkat Pendidikan Terhadap Harapan dan Persepsi Pasien

\begin{tabular}{|c|c|c|}
\hline Korelasi & Nilai & Keterangan \\
\hline $\begin{array}{l}\text { Tingkat } \\
\text { pendidikan } \\
\text { terhadap } \\
\text { harapan }\end{array}$ & $\begin{array}{l}r=0,231 \\
p=<0,05\end{array}$ & $\begin{array}{l}\text { Ada korelasi } \\
\text { signifikan, arah } \\
\text { korelasi } \\
\text { positif,tingkat } \\
\text { korelasi lemah }\end{array}$ \\
\hline $\begin{array}{l}\text { Tingkat } \\
\text { pendidikan } \\
\text { terhadap } \\
\text { persepsi }\end{array}$ & $\begin{array}{l}r=0,351 \\
p=<0,05\end{array}$ & $\begin{array}{l}\text { Ada korelasi } \\
\text { signifikan, arah } \\
\text { korelasi positif, } \\
\text { tingkat korelasi lemah }\end{array}$ \\
\hline
\end{tabular}

Berdasarkan hasil penelitian secara umum yang ditunjukkan pada tabel 1 . setelah diuji menggunakan uji Spearman, ada korelasi yang signifikan antara tingkat pendidikan dengan harapan pasien terhadap pelayanan kefarmasian di Apotek "X" Daerah Seminyak. Korelasi tersebut menunjukkan arah positif yang menunjukkan semakin tinggi tingkat pendidikan maka harapan pasien terhadap pelayanan kefarmasian di Apotek "X" di Daerah Seminyak semakin tinggi. Namun,tingkat korelasi tersebut termasuk lemah karena ada banyak faktor yang mempengaruhi korelasi tersebut.

Menurut Zeithaml etal., (2003), terdapat empat faktor yang mempengaruhi persepsi dan ekspektasi pasien,yaitu sebagai berikut:

1. Apa yang didengar pasien dari pasien lainnya (worth of mouthcommunication).

2. Karakteristik individu yang dipengaruhi kebutuhan pribadi (personnel needs).

3. Pengalaman masa lalu (past experience) dalam menggunakan pelayanan.

4. Komunikasi dengan pihak eksternal (external communication) dari pemberi layanan memainkan peranan kunci dalam membentuk ekspektasi pelanggan.

Hasil uji Spearman menunjukkan ada korelasi yang signifikan antara tingkat pendidikan dengan persepsi pasien terhadap pelayanan kefarmasian di Apotek "X" Daerah Seminyak. Korelasi tersebut menunjukkan arah positif yang menunjukkan semakin tinggi tingkat pendidikan maka persepsi pasien terhadap pelayanan kefarmasian di Apotek "X" di Daerah Seminyak semakin tinggi. Namun,tingkat korelasi tersebut termasuk lemah karena ada banyak faktor yang mempengaruhi korelasi tersebut.

Menurut Miftah Thoha (2003), faktor-faktor yang mempengaruhi persepsi seseorang adalah sebagai berikut : 
1. Faktor Internal: Perasaan, sikap dan kepribadian individu, prasangka, keinginan atau harapan, perhatian (fokus), proses belajar, keadaan fisik, gangguan kejiwaan, nilai dan kebutuhan juga minat, serta motivasi.

2. Faktor Eksternal: Latar belakang keluarga, informasi yang diperoleh, pengetahuan dan kebutuhan sekitar, intensitas, ukuran, keberlawanan, pengulangan gerak, hal-hal baru dan familiar atau ketidakasingan suatu objek.

Tabel 2. Hasil Uji Spearman Terhadap Korelasi Antara Tingkat Pendidikan Terhadap Harapan yang terbagi dalam Lima Dimensi Pelayanan

\begin{tabular}{|c|c|c|}
\hline Korelasi & Nilai & Keterangan \\
\hline $\begin{array}{l}\text { Pengaruh tingkat } \\
\text { pendidikan thd } \\
\text { harapan dimensi } \\
\text { reliability }\end{array}$ & $\begin{array}{l}\mathrm{r}=0,287 \\
\mathrm{p}=<0,05\end{array}$ & $\begin{array}{c}\text { Ada korelasi } \\
\text { signifikan arah } \\
\text { korelasi positif, } \\
\text { tingkat korelasi } \\
\text { lemah }\end{array}$ \\
\hline $\begin{array}{l}\text { Pengaruh tingkat } \\
\text { pendidikan thd } \\
\text { harapan dimensi } \\
\text { responsiveness }\end{array}$ & $\begin{array}{l}r=0,182 \\
p=<0,05\end{array}$ & $\begin{array}{l}\text { Ada korelasi } \\
\text { signifikan, arah } \\
\text { korelasi positif, } \\
\text { tingkat korelasi } \\
\text { sangat lemah }\end{array}$ \\
\hline $\begin{array}{l}\text { Pengaruh tingkat } \\
\text { pendidikan thd } \\
\text { harapan dimensi } \\
\text { assurance }\end{array}$ & $\begin{array}{l}\mathrm{r}=0,129 \\
\mathrm{p}=>0,05\end{array}$ & $\begin{array}{c}\text { Korelasi tidak } \\
\text { signifikan, arah } \\
\text { korelasi positif, } \\
\text { tingkat korelasi } \\
\text { sangat lemah }\end{array}$ \\
\hline $\begin{array}{l}\text { Pengaruh tingkat } \\
\text { pendidikan thd } \\
\text { harapan dimensi } \\
\text { tangibles }\end{array}$ & $\begin{array}{l}r=-0,058 \\
p=>0,05\end{array}$ & $\begin{array}{c}\text { Korelasi tidak } \\
\text { signifikan ian, } \\
\text { arah korelasi } \\
\text { negatif, tingkat } \\
\text { korelasi sangat } \\
\text { lemah }\end{array}$ \\
\hline $\begin{array}{l}\text { Pengaruh tingkat } \\
\text { pendidikan thd } \\
\text { harapan dimensi } \\
\text { empathy }\end{array}$ & $\begin{array}{l}\mathrm{r}=0,369 \\
\mathrm{p}=<0,05\end{array}$ & $\begin{array}{c}\text { Ada korelasi } \\
\text { signifikan, arah } \\
\text { korelasi positif, } \\
\text { tingkat korelasi } \\
\text { lemah }\end{array}$ \\
\hline
\end{tabular}

Tabel 3. Hasil Uji Spearman Terhadap Korelasi Antara Tingkat Pendidikan Terhadap Harapan yang terbagi dalam Lima Dimensi Pelayanan

\begin{tabular}{ccc}
\hline Korelasi & Nilai & Keterangan \\
\hline Pengaruh tingkat & $\mathrm{r}=0,511$ & Korelasi tidak \\
pendidikan thd & $\mathrm{p}=>0,05$ & $\begin{array}{c}\text { signifikan arah } \\
\text { kerelasi positif, } \\
\text { persepsi dimensi } \\
\text { reliability }\end{array}$ \\
$\begin{array}{c}\text { tingkat korelasi } \\
\text { sedang }\end{array}$ \\
$\begin{array}{c}\text { Pengaruh tingkat } \\
\text { pendidikan thd } \\
\text { persepsi dimensi } \\
\text { cresponsiveness }\end{array}$ & $\mathrm{r}=0,258$ & $\begin{array}{c}\text { Ada korelasi, arah } \\
\text { korelasi positif, }\end{array}$ \\
& & $\begin{array}{c}\text { tingkat korelasi } \\
\text { lemah }\end{array}$ \\
\hline
\end{tabular}

\begin{tabular}{|c|c|c|}
\hline Korelasi & Nilai & Keterangan \\
\hline $\begin{array}{l}\text { Pengaruh tingkat } \\
\text { pendidikan thd } \\
\text { persepsi dimensi } \\
\text { assurance }\end{array}$ & $\begin{array}{l}\mathrm{r}=0,302 \\
\mathrm{p}=<0,05\end{array}$ & $\begin{array}{l}\text { Ada korelasi } \\
\text { signifikan, arah } \\
\text { korelasi positif, } \\
\text { tingkat korelasi } \\
\text { lemah }\end{array}$ \\
\hline $\begin{array}{l}\text { Pengaruh tingkat } \\
\text { pendidikan thd } \\
\text { persepsi dimensi } \\
\text { empathy }\end{array}$ & $\begin{array}{l}r=0,214 \\
p=<0,05\end{array}$ & $\begin{array}{c}\text { Ada korelasi } \\
\text { signifikan, arah } \\
\text { korelasi positif, } \\
\text { tingkat korelasi } \\
\text { lemah }\end{array}$ \\
\hline $\begin{array}{l}\text { Pengaruh tingkat } \\
\text { pendidikan thd } \\
\text { persepsi dimensi } \\
\text { tangibles }\end{array}$ & $\begin{array}{l}\mathrm{r}=0,191 \\
\mathrm{p}=<0,05\end{array}$ & $\begin{array}{c}\text { Ada korelasi } \\
\text { signifikan, arah } \\
\text { korelasi positif, } \\
\text { tingkat korelasi } \\
\text { lemah }\end{array}$ \\
\hline
\end{tabular}

Tabel 2 menunjukkan korelasi yang signifikan antara tingkat pendidikan dan harapan terdapat pada dimensi reliability, responsiveness dan empathy. Tabel 3 menunjukkan korelasi yang signifikan antara tingkat pendidikan dan harapan terdapat pada dimensi responsiveness, assurance, tangible dan empathy.

\section{SIMPULAN}

Dari hasil penelitian dapat disimpulkan bahwa:

1. Ada korelasi signifikan antara tingkat pendidikan dan harapan terhadap pelayanan kefarmasian di apotek " $\mathrm{x}$ " daerah Seminyak dengan arah korelasi positif dan tingkat korelasi lemah.

2. Korelasi antara tingkat pendidikan dan persepsi terhadap pelayanan kefarmasian di apotek "x" daerah Seminyak menunjukkan hasil yang signifikan dengan arah korelasi positif dan tingkat korelasi lemah.

\section{DAFTAR PUSTAKA}

Departemen Kesehatan Republik Indonesia. 2014. Keputusan Menteri Kesehatan Republik Indonesia No. 1027 Tahun 2004 tentang Standar Pelayanan di Apotek.(1-6).

Miftah Thoha. 2003. Perilaku Organisasi. Edisi Pertama, Cetakan Keempatbelas. Jakarta : PT Raja Grafindo Persada.

Nursalam, 2001, Metodologi Riset Keperawatan, CV Sagung Seto : Jakarta 
Parasuraman, A. Zeithaml, Valerie A., dan L.

Berry. 1991. DeliveringQuality Service.

New York : The Free Press A Divission of Mac Millan inc.

Tjiptono. F, 2008, Service Management Mewujudkan Layanan Prima, Penerbit ANDI: Yogjakarta. 